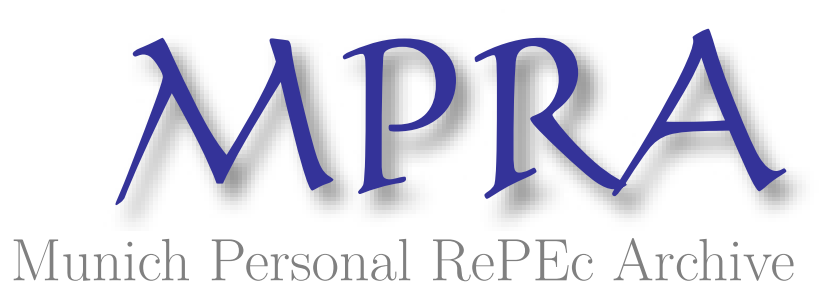

\title{
The Macroeconomic Determinants of Commodity Prices
}

Reinhart, Carmen and Borensztein, Eduardo

University of Maryland

June 1994

Online at https://mpra.ub.uni-muenchen.de/6979/

MPRA Paper No. 6979, posted 09 Apr 2008 04:47 UTC 
INTERNATIONAL MONETARY FUND

\section{STAFF \\ PAPERS}

\section{The Macroeconomic Determinants of Commodity Prices}

EDUARDO BORENSZTEIN AND CARMEN M. REINHART

Vol. 41 No. 2

JUNE 1994 



\title{
The Macroeconomic Determinants of Commodity Prices
}

\author{
EDUARDO BORENSZTEIN and CARMEN M. REINHART*
}

The "traditional structural approach" to determining real commodity. prices has relied exclusively on demand factors as the fundamentals, that explain the behavior of commodity ' prices. This framework, however, has been unable to explain the marked and sustained weakness in these prices during the 1980s and 1990s. This paper extends that framework in two important directions: first, it incorporates commodity.' supply in the analysis, capturing the impact on prices of the sharp increase in commodity. exports of developing countries during the debt crisis of the 1980s. Second, it takes a broader view of "world" demand that extends; beyond the industrial countries and includes output developments. in Eastern Europe and the former Soviet Union. The empirical results support these extensions, as both the fit of the model improves substantially and, more important, its ability' to forecast increases markedly. [JEL E30, F39]

$\mathrm{C}$ OMMODITY MARKETS playa central role in transmitting disturbances internationally by linking commodity importing countries to commodity suppliers. Given the marked fluctuations in both prices and volumes in recent years, it is important to re-examine the underlying macroeconomic factors that have an impact on this market and that must

- Eduardo Borensztein. a Deputy Division Chief in the Research Department, holds a doctorate from the Massachusetts Institute of Technology. Carmen M Reinhart is an Economist in the Research Department. . She holds a Ph.D. from Columbia University.

The authors wish to thank John Cuddington, Jonathan Ostry, Vincent Remhart, and Peter Wickham for helpful comments and suggestions and Elke MeldauWomack for discussions and help with the data. Special thanks to Ximena Cheetham and Stephanie Schmitt-Grohe for excellent research assistance and suggestions. 
be taken into account in the design of policy. particularly for those countries that rely heavily on primary commodity exports and that are facing substantial terms of trade shocks. Further. the need to understand the factors that influence the behavior of commodity prices has taken on a new urgency in recent years. as non-oil commodity prices have fallen sharply and persistently in real terms since the early 1980s. Although this decline affects all commodity producing countries in some measure. those with the least diversified production structure suffer the largest impact.. Moreover, this latter group of countries tends to have less flexible economic systems. making substitution away from commodity production more difficult or costly, and encompasses many of the poorest countries in the world.

The conventional analysis of commodity markets mimics the empirical strategy applied to other key macroeconomic variables-namely, to try to identify; a stable and predictable relationship between commodity prices and two or three macroeconomic variables. Whereas markets for individual commodities are affected by a variety of specific factors in their day-to-day evolution, the aggregate index of non-oil commodities has been treated as a macroeconomic variable whose movements, on a quarterly or annual basis. are related to prevailing macroeconomic conditions. Studies that have stressed a structural approach to commodity price determination have found that two (demand-side) variables did well in explaining the variation of commodity prices: the state of the business cycle in industrial countries and the real exchange rate of the U.S. dollar.! This line of research. including the work of Chu and Morrison (1984 and 1986), Dornbusch (1985), and. more recently, Gilbert (1989). generally involves partial equilibrium models that treat the determinants of commodity prices (both conceptually and empirically) as exogenous.

During the early 1980s. industrial production in the industrial countries was weak. as several countries experienced prolonged and deep recessions, and the dollar appreciated by nearly 50 percent in real terms. In this setting, the "demand-driven" framework explained much of the observed weakness in real commodity prices (which fell by 31 percent in that period). After 1984, however, despite a weakening dollar and a substantial rebound in the growth of output of several of the major industrial countries. real commodity prices remained soft, puzzling many

IThe role of the real exchange rate of the U.S. dollar in this framework is to correct for the fact that commOdityprices are measured by a dollar-denominated index and deflated by a dollar-denominated price index. whereas the relevant measure for the non-U.S. industrial countries is the price of commodities relative to output prices in those countries. 
commodity market analysts and further worsening the predicament. of the many developing economies that are primary commodity exporters : (see Morrison and Wattleworth (1987)). By late 1984. the demand-driven framework began systematically to overpredict real commodity prices by wide margins, and the forecasts have continued to be offtrack. This persistent overprediction, in turn. suggested that one or more important variables were being left out of the analysis.

A number of reasons have been put forward to explain the persistent weakness in commodity prices since 1984, based essentially on anecdotal evidence rather than on a formal systematic approach. For instance, the response in developing countries to the debt crisis of the 1980s and the more recent economic developments in the economies in transition in Eastern Europe and the former Soviet Union stand out as major shocks considered to have had considerable impact on international commodity markets. Specifically, it has been argued that the acceleration in primary commodity supplies since the mid-1980s has been partially explained by the debt crisis, as developing countries expanded commodity exports in an attempt to service burgeoning debt obligations (see, for instance, Aizenman and Borensztein (1988) and Gilbert (1989)).2 With respect to the economies in transition, the impact on the international commodity market has been through two channels: weaker demand, as incomes and consumption have fallen dramatically in recent years, and a sharp increase in the supply of several primary ' commodities. The contraction in demand is reflected in the sharp declines in imports of a broad spectrum of commodities, while the supply effect is evident in the staggering increases in exports of various metals by countries of the former Soviet Union.

The purpose of this paper is to identify the main economic fundamentals behind the behavior of commodity prices. particularly the recent weakpess, and to quantify, how the relative importance of each of these factors has evolved over time. We extend the "traditional structural approach" described above by incorporating these two important developments in international commodity markets of the 1980s and 1990s. The empirical analysis is based on quarterly data for 1970:1-1992:III. As in the theoretical model outlined in Reinhart (1991), we incorporate commodity supplies as a determinant of commodity prices. thus capturing the

$20 f$ course. other important factors are behind the surge in commodity supplies. Specifically. technological innovation and increases in productivity in the commodity producing sector. agricultural policies in the industrial countries and the breakdown of several international commodity agreements (leAs) have all had a significant impact on supply conditions during the 19805 and 1990s (see Reinhart and Wickham (1994») 
impact on prices of the sharp increase in the commodity exports of the developing countries. In addition, we take a broader view of "world" aggregate demand that extends beyond the major industrial countries and includes output developments in Eastern Europe and the former Soviet Union.

The main results can be summarized as follows: first, as predicted by theory, the constructed proxy variable for commodity. supplies affects commodity. prices in a negative and predictable manner. The inclusion of this measure of supply markedly improves the fit of the structural model and, more important. significantly reduces the out-of-sample overpredietion of real commodity prices that have plagued demanddriven structural models since the mid-1980s. In effect. supply developments appear to account for the bulk of the variation in real commodity prices during 1985-88. Second. whereas output in Eastern Europe and the former Soviet Union appears to have played a relatively minor role over the entire sample period (1971-92)-adding little to the overall fit of the model or to the model's predictive ability prior to 1989-these developments became increasingly important in the more recent period. When this broader measure of world demand is employed, the problem of systematic overprediction disappears. In addition, variance decompositions confirm that the relative importance of developments in transition economies in accounting for the explained variability in real. commodity prices more than quadrupled in the post-1988 period. More generally, the results indicate that although the full structural model does not outperform a random walk forecast of real commodity prices for short-term forecast horizons ( 1 to 4 quarters ahead), the structural model consistently outperforms the random walk predictions over a longer-term forecast horizon (5 to 31 quarters) and captures the major turning points in real commodity prices during 1985-92.

Section I summarizes some of the stylized facts on recent developments in commodity prices and their potential determinants; the focus is on documenting supply conditions and on discussing the relevant developments in Eastern Europe and the former Soviet Union. Section II provides the theoretical structure that forms the basis for the empirical pan of the analysis, which is presented in Section III.. The empirical section discusses some of the problems of the earlier models. It is shown that demand-side only models suffer from both misspecification and simultaneity bias. $^{3}$ Proxies for world commodity supply and for demand in the transition economies are then included as determinants of real

\footnotetext{
${ }^{3}$ See Engiander (1985) for a review of this literature.
} 
commodity prices. The section assesses the robustness of the proposed structural model by comparing its out-of-sample forecasting performance to a "naive" model such as Meese and Rogoff (1983a and 1983b) and concludes by examining how the relative importance of the macroeconomic determinants has evolved over time.

\section{Developments in Commodity Markets}

The decline in the prices of non-oil commodities in real terms in the past decade has been remarkable. By mid-1993, the relative price of non-oil commodities had declined 42 percent relative to 1980 . and 63 percent relative to its peak in early 1974 (Figure 1. Panel A).4 From a historical perspective. the decline is also exceptional. . In 1982. the relative price of non-oil commodities went below its previous historical minimum of 1932, and by mid-1993 it was at its lowest level in over ninety years. ${ }^{\mathrm{S}}$ Although market conditions vary from one commodity to another. Reinhart and Wickham (1994) show that the downward trend has been quite generalized and is evident in the major commodity groupings, such as the index for all commodities and the beverages. food, and metals indices. The encompassing nature of the phenomenon, in turn, suggests that common factors have been responsible for the price decline.

As Panel A of Figure 1 illustrates, the other prominent development. in the recent evolution of commodity markets is that the decline in prices has been accompanied by a vigorous growth in the volume of imports of non-oil commodities by industrial countries. ${ }^{6}$ Since 1983 , this volume index has almost doubled, even though, during the same period, the GDP

${ }_{4}$ We measure the relative price of non-oil commodities as the IMF allcommoditv index deflated bv the U.S. GNP deflator.. Both indices are in U.S. dollars. Different measures of the commodities price index or the deflator do not alter the outlook significantly.

D During 1993:II1-1994:I, , commodity prices rebounded from their mid-1992 lows. This moderate recoverv has been associated with the rebound in economic activity in the United States: as GNP growth accelerated to an annualized rate of 7.5 percent during the final quarter of 1993 .

6World commodity supply is an unobserved variable. and most likely, any constructed proxy for it (tncluding the one used here) is subject to measurement error. However. the principal reason for using an index of the volume of commodity imports of the industrial countries as a measure of supply rather than. say, recorded exports of primary commodities from developing countries is the accessibility and reliability of the data. According to the country classification strategy used in the World Economic Outlook. there are 130 developing countries (of which 68 are non-oil commodity exporters). Since both the timeliness and reliability of the data vary markedly across such a large set of countries, especially at quarterly frequencies. this diversity is expected to exacerbate the measurement error problem. 
Figure 1. Factors Affecting Commodity.' Markets

$(1980-1.0)$

Panel A.

Non-Oil Commodity Prices and World Commodity : Supply

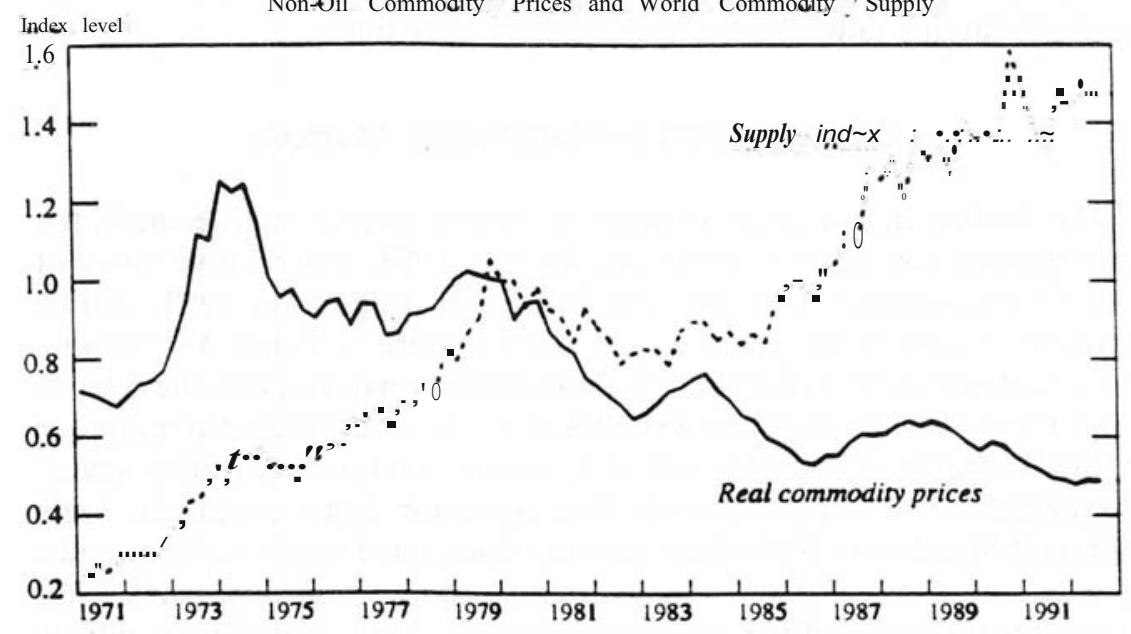

Panel B.

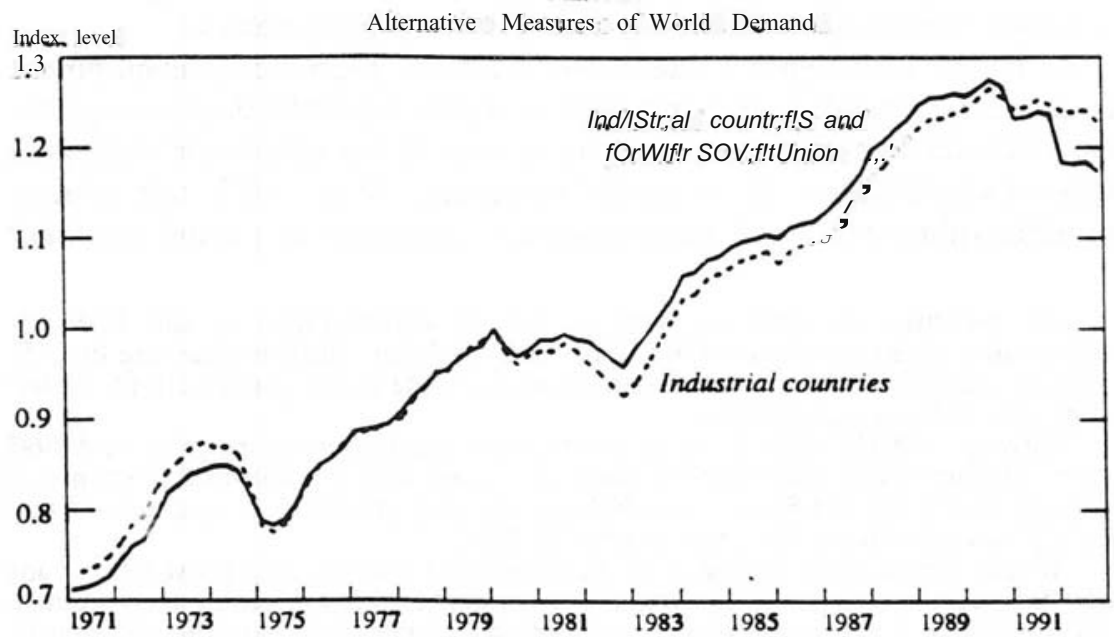

Sources: IMF, International Financial Statistics and World Economic Outlook, and the authors.

Notes: The supply index is based on industrial countries' impons of primary commodities. The demand index is based on industrial production for industrial countries and real GDP for the former Soviet Union. 
of the industrial countries grew by less than 30 percent. . Imports of non-oil commodities also grew faster than those of other goods. as world imports of all types of goods increased by approximately 70 percent in real terms during the same period. This large increase in the volume of commodity production and trade points to the importance of supply-side factors in explaining price developments. As Figure 1 highlights, the decline in prices of the 1980s and 1990s is not entirely due to an inward shift in the demand for commodities; the significant outward shift in available supply must also have played a key role.

Several concurrent factors appear to explain the acceleration in supply growth over the past decade. As noted by Reinhart and Wickham (1994) and World Bank (1994). technological developments have played a key role in boosting output of primary commodities. particularly for several agricultural commodities. Agricultural policies in the industrial countries and the breakdown of several leAs further expanded supplies available. For developing countries. a number of additional factors contributed to this expansion. The unfolding of the debt crisis in the early 1980s confronted many developing countries with considerably more restricted borrowing opportunities in international financial markets. Balance of payments adjustments were required. which produced policies geared to encouraging exports and expanding commodity supplies in many developing countries. In the midst of the debt crisis (1984-88), world commodity supply grew at an annual rate of 13 percent, or about three times as fast as the annual rate of growth of 4.8 percent of the previous ten years. More generally, the structural reforms initiated by many developing countries in the later part of the 1980 s also had a positive impact on commodity supplies. As developing countries opened their economies to international trade and adjusted their economic policies in a more market-oriented direction. productive resources flowed toward sectors with comparative advantage, which in many cases include primary products.

Since 1990, a second major shock has affected commodity markets. namely, the aftermath of the collapse of centrally planned systems in the countries of Eastern Europe and, particularly, the former Soviet Union. These countries account for large shares of the commodity markets on both the import side (mostly grains and other foodstuffs) and the export side (especially metals). The demand for imported commodities in transition economies fell concomitantly. with the fall in output and aggregate demand that followed the collapse of the old economic systems. Some examples of the decline in imports of commodities by the former Soviet Union are shown in Table 1. Therefore, the inclusion of the countries of the former Soviet Union can significantly alter the behavior of our mea- 
Table 1. Former Soviet Union: Demand for Selected Commodities

\begin{tabular}{lcc}
\hline Import & $\begin{array}{c}\text { Percent change. } \\
\text { volumes of }\end{array}$ & $\begin{array}{c}\text { Imports as share of } \\
\text { world imports in } \\
\text { (percentl }\end{array}$ \\
\hline Cocoa' & $-489-92-1$ & $\underline{1989}$ \\
Com & -62.7 & 26.0 \\
Tea & -55.7 & 26.9 \\
Wheat & $-170^{\mathrm{b}}$ & 21.3 \\
\hline
\end{tabular}

Sources: World Grain Situation and Outlook. and International Tea Comminee .

- Grindings of raw cocoa (close to imports).

bThrough November 1993.

sure of world demand for commodities. This effect is made plain by Panel $\mathrm{B}$ of Figure 1. which shows that there was little difference up to and including 1988 between a measure of aggregate demand that included the economies in transition and the measure more often used that comprises only Western industrial countries. Hence. a priori. no substantive differences in the econometric results would be expected by using one or the other measure. Since 1989. however. these two indices paint a very different picture of aggregate demand conditions. The industrial country' index suggests a flat demand for commodities whereas the more comprehensive measure signals a recession comparable in magnitude to the recession following the first oil shock in 1973 and the more recent downturn in the early 1980s.

However. the impact of economic developments in Eastern Europe and the former Soviet Union on international commodity markets has not been limited to a reduction in their demand for primary commodities. In effect.. some of the more substantial effects have been on the supply side. especially in the metals markets. where the former Soviet Union is an important supplier. As can be seen in Table 2, this surge in exports largely reflects the sharp contraction in the level of domestic activity in the defense industry and in other poorly competitive manufacturing branches. many of which are relatively metal intensive. Thus, the decline in the domestic demand for metals and disruptions in interrepublican trade appear to have generated sharp increases in exports by the former Soviet Union to Western markets. Other factors may have also contributed to the increase in the volume of exports of metals: (1) increased profitability in energy-intensive metals production and exports, owing to the still very low domestic price of energy; (2) arbitrage opportunities arising from discrepancies between domestic and international prices in the context of partial price and trade liberalization: (3) a reduction in 
Table 2 Supple of Selected Commodities from the Eormer Soviet Union

\begin{tabular}{lcc}
\hline Exports_of & $\begin{array}{c}\text { Percent chanl!:e, } \\
1989-92-\end{array}$ & $\begin{array}{c}\text { Former Soviet Union } \\
\text { exports as share of } \\
\text { world exports., 1992 } \\
\text { (percent) }\end{array}$ \\
\hline Aluminum & 219.4 & 8.3 \\
Copper & 72.1 & 5.4 \\
Zinc & $\underline{686.9}$ & 2.2 \\
\hline
\end{tabular}

Source: World Metal Statistics.

stock levels that are no longer justified from national security or economic standpoints; and (4) export activity linked to capital flight.. Overall, the increase in exports of metals and the fall in imports of some grains and other commodities since 1989 in the former Soviet Union have contributed to the observed weakness in the aggregate prices of primary products.

These stylized facts provide clues for the econometric investigation. Although the macroeconomic conditions in industrial countries have traditionally been considered the main determinant of commodity price developments, it seems evident that other forces have played a significant role over the recent past.. Based on the arguments made in this section, a supply variable should be included to account for the booming exports of primary products? and the change in the demand for commodities of the former Soviet Union.

\section{A Framework}

In the analysis that follows it is assumed that the commodity is nonstorable and internationally traded. The assumption of nonstorability is made for simplicity. Whereas the storability of commodities affects the dynamics of prices through the presence of arbitrage conditions and financial return requirements, it does not alter the identification of the fundamental determinants of commodity prices. which is the main objective of this paper.

We assume that there are three countries (or country blocs), two of which are industrial commodity importers, and the third country can be considered a developing commodity supplier..

\footnotetext{
data.

7 Morrison and Wattleworth (1987) also consider supply effects using annual
} 


\section{Demand for Commodities}

The demand for commodities is usually formulated as the demand for an input that is used for the production of final goods. Two countries demand commodities as inputs: the United States and an aggregate of the rest of the industrial countries. Production in each one of these two countries takes place under a Cobb-Douglas technology. By duality, the cost function corresponding to that technology is the following:

$$
C(y, q, \omega)=y A q^{\alpha} \Omega,
$$

where $y$ is the level of output in the United States, $q$ is the price of non-oil commodity inputs relative to the price of U.S. output. , and $A$ is a constant. $\mathrm{n}$ represents the contribution of other inputs to cost and is given by the product of functions of their real prices:

$$
\mathrm{n}=\text { Ilwr', }
$$

where the $W_{;,,} i=1, \ldots, N$ represent real product prices of all the other inputs and factors used in production. Similarly, for the other industrial countries, the dual cost function is given by

$$
C^{*}\left(y^{*}, q, R, w^{*}\right)=y^{*} A^{*}(q R) a n^{*},
$$

where $R$ is the ratio of the price of U.S, output to the output of other industrial countries (the real exchange rate of the U.S. dollar), and variables with a superscript asterisk have the same definition as in the $\mathrm{U}, \mathrm{S}$. case but correspond to the "other industrial country" grouping. Conditional factor demands can then be obtained by the corresponding partial derivative of the cost functions. Therefore, the demand for commodities by the United States and other industrial countries will be given by

$$
M(y, q, w)=y \text { Aaqa- } n
$$

and

$$
M^{*}\left(y^{*}, q, R, \omega^{*}\right)=y^{*} A^{*} \alpha q^{\alpha-1} R^{\alpha-1} \Omega^{*} .
$$

\section{Supply and Market Clearing}

An aggregate of developing countries produce and export the commodity, the supply of which is assumed to be fixed at a point in time. In this simplest framework, we do not attempt to formulate an aggregate supply function for commodities, largely because of the diversity of economic conditions in the broad spectrum of producer countries. Further, 
past studies have had limited success in endogenizing supply. For instance. one of the determinants of the supply increase for a set of developing countries was the debt crisis in the 1980s. which forced them to improve returns to commodity exporters, among other adjustments. Gilbert (1989) tried to capture this effect by using the debt-service ratio for a group of developing countries as an explanatory variable for commodity prices but had limited success. One problem is that although the debt crisis provided the backdrop for efforts to increase exports of commodities, indicators such as debtlGDP ratios do not provide good proxies for the incentives offered to commodity suppliers; on a quarterly basis. Also. developing countries in Asia. without debt-servicing difficulties. have liberalized their trade regimes and improved export incentives. In addition. technological improvements. which are difficult to quantify. empirically as they are largely unobservable, have also played a key role in boosting commodity supply in recent years. Hence this simple framework treats commodity supplies as exogenous. ${ }^{8}$

Commodity prices will then be determined to equalize existing supply with the total demand by the two countries:

$$
Q=M+M^{*} \text {. }
$$

To avoid inconvenient nonlinearities, we will assume that the relative shares in commodity demand by the two countries remain constant. namely:

$$
\pi^{\frac{M}{+}} M=x ; \quad \frac{M-}{M^{+}}=1-x-
$$

We can then form a composite demand for commodities using equations (4) and (5) above. The market-clearing commodity price can then be obtained by equating supply and (composite) demand and is givenin log terms-by the following expression:

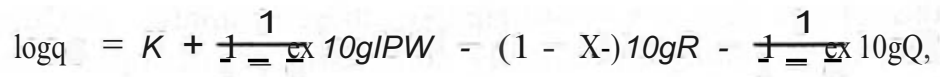

where $\log I P W=\mathrm{X}-\operatorname{logy}+(1-\mathrm{X}-)_{0} \log ^{*}$ represents the aggregate level of production in the two countries (the acronym standing for world industrial production), and $K$ includes constant terms and terms in the other factors of production.

Equation (8) is a partial equilibrium specification of the market for commodities. A general equilibrium representation should specify the ties. 
endogenous determination of the supply of commodities Q, of the real exchange rate $R$, and of the level of composite output IPW. These variables will be determined jointly by aggregate demand conditions. factor market equilibrium. and government policies in the two countries and in the countries in which production of commodities takes place. Such a model, as shown in Reinhart: (1991), yields a specification of real commodity prices comparable to equation (8).

Having outlined the minimal structure required to link real commodity prices to several key macroeconomic determinants. the next section will examine the empirical relevance of the suggested framework.

\section{Empirical Results}

\section{Problems with the Conventional Approach}

Almost all the work on commodity price determination has used a single-equation framework. The analyses differ by the indices used. estimation period, frequency. and exact set of right-hand side variables. However, ordinary least-squares (OLS) is the universal technique of choice.

Consider. for example, the examination of the commodity priceexchange rate linkage in Dornbusch (1985 and 1986). The basic equation estimated is

$$
q,={ }_{30}+\left(3 \mid I P l v, .+{ }_{(3 z \mathrm{R},}+\mathrm{Lt}_{,},\right.
$$

where. as before. $I P W$ is a measure of industrial production in the major industrial countries (see fn. I above). Using first differences of the logs of the variables. Dornbusch estimates the coefficients for industrial production and the real exchange rate to be about 2.25 and -1.5 . respectively. Although the signs are as anticipated. these estimates. as Dornbusch relates. are troubling. Specifically, commodity prices appear to be excessively sensitive to fluctuations in the real exchange rate. As shown in the previous section. the elasticity of commodity prices with respect to the real exchange rate that clears the commodity market is given by $-(1-h)$, which is between zero and one in absolute value. If the two commodity importing countries (or blocs of countries) are equal in size and share the same technology, we would expect a value closer to -0.5 rather than the -1.5 found. ${ }^{9}$

9The share of the United States in the total trade of primary commodity exporting countries with industrial countries is about the same size as the share of the 13-country bloc used in the empirical work. 
Table 3. Determinants of Real Commodity Price: "Conventional".' Demand-Driven Model. 1971:/-1992:1II'

\begin{tabular}{lcccr}
\hline $\begin{array}{l}\text { Constant } \\
\text { term }\end{array}$ & $\underline{P / v}$ & $B$, & $R^{2}$ & D.W. \\
\hline-0.02 & 1.99 & -1.52 & 0.38 & 1.91 \\
$(-4.22)$ & $\underline{(5.28)}$ & $\underline{(-\underline{3.40)}}$ & & \\
\hline
\end{tabular}

- Definitions of all the variables appear in Appendix . II. First differences of log levels are used for all variables. The above equations include two lags for production and the real exchange rate. The numbers in parentheses are t-statlstics.

This result is easily replicated. We estimated equation (9) using the quarterly data from 1971:1 to 1992:II1 for the IMF all-commodity index: OLS techniques yield the coefficients given in Table 3. However. as noted in the previous section. industrial production (a weighted average of y and $\left.y^{*}\right)$ is an endogenous variable. Further. as shown in Reinhart (1991), in a general equilibrium setting, real commodity prices and the real exchange rate are jointly determined, so the real exchange rate is also not an appropriate right-hand side variable. Therefore, a specification such as (9) estimated by OLS suffers from simultaneity bias. Further, the omission of a commodity supply measure and the possible mismeasurement of aggregate demand (Eastern Europe and the former Soviet Union are excluded from previous studies) suggests a fundamental rnisspecification problem. Not surprisingly, the parameter estimates are unreliable.

To illustrate the simultaneity bias problem we perform the Hausman test for contemporaneous correlation (for a discussion, see Leamer (1985») The real exchange rate. $R^{\prime \prime}$ can be decomposed into two parts: a prediction generated by an auxiliary' regression using variables known to be strictly exogenous (therefore uncorrelated with the error term) and all else. ${ }^{10}$ Simultaneity bias appears as a correlation between the residuals from the auxiliary regression and the residuals of the structural equation. Or, as Hausman (1978) has shown. if the actual variable is significant in a regression that includes both the actual and the projection. simultaneity. bias is present.

The results are presented in Table 4. As anticipated. the inclusion of an instrumental projection for the real exchange rate in a specification

IOThe instrument set used for this exercise includes two lags of industrial production, two lags of the real exchange rate, real oil prices. and the U.S. fiscal deficit. The fiscal deficit has been identified as an important determinant of the U.S. real exchange rate (see, for example, Reinhart (1991) and Alogoskoufis and Varangis (1992». 
Table 4. The Hausman Test for Simultaneity, 1971:I-1992:III

\begin{tabular}{lccccc}
\hline $\begin{array}{l}\text { Constant } \\
\text { term }\end{array}$ & $I P W_{\mathrm{t}}$ & $R_{\mathrm{f}}$ & $\begin{array}{c}\text { Instrument } \\
\text { for } R,\end{array}$ & $R^{2}$ & $\mathrm{DWW}$ \\
\hline-0.02 & 2.07 & -0.73 & 0.61 & 0.42 & 1.85 \\
$(-2.72)$ & $(5.56)$ & $\underline{(-3.93)}$ & $\underline{(1.97)}$ & & \\
\hline
\end{tabular}

- As before. first differences of log levels are used for all variables. The above equations include two lags for industrial. production and the reall exchange rate. The variables used to construct an instrument for the real exchange rate are ItS own lagged values. current and lagged values of world production. the real U.S. fiscal deficit. and real oil prices tsee Appendix, II for details). The numbers in parentheses are (-statistics.

such as equation (9) did not eliminate the significance of the real exchange rate. indicating the presence of simultaneity bias. Hence, the implausible parameter estimates shown in Table 3 follow from an invalid inference resulting from the wrong estimation strategy. In the remainder of this section, simultaneity is dealt. with by an estimation strategy that treats all the right-hand side variables as potentially endogenous.

However, implausible parameter estimates are not the only problem associated with this model.. The empirical performance, as gauged by its forecasting performance out of sample, deteriorates considerably after 1984 as already noted by Morrison and Wattleworth (1987). In Figure 2 the dynamic forecasts from the estimation of equation (9) are plotted under the label "modell.". Figure 2 shows that after 1984 this model loses track of the evolution of commodity prices; specifically, there is a systematic overprediction that continues to the present.. The decline in commodity prices in the early 1980s was accompanied by recession in several industrial countries and a strong appreciation of the dollar (factors captured in the demand-driven model). Similarly, during 1983-84 the rebound in economic activity in most industrial countries would predict a recovery in commodity prices. However. in subsequent years the real exchange rate of the dollar depreciates sharply and growth remains strong, both factors that would suggest a rebound in real commodity prices. Commodity prices do recover by a modest 13.5 percent in 1986-89. However. as Figure 2 illustrates, the predicted recovery in that same period is 27 percent, far exceeding actual experience. The overprediction persists through 1992, highlighting the importance of some of the omitted variables. We assess below the empirical relevance of two key omitted variables. Specifically, we examine the role of commodity supply in affecting commodity prices and the impact of the decline in demand from the former Soviet Union. 
Figure 2. Real Commodity Prices: Actual arui Forecast

$(1980=1.0)$

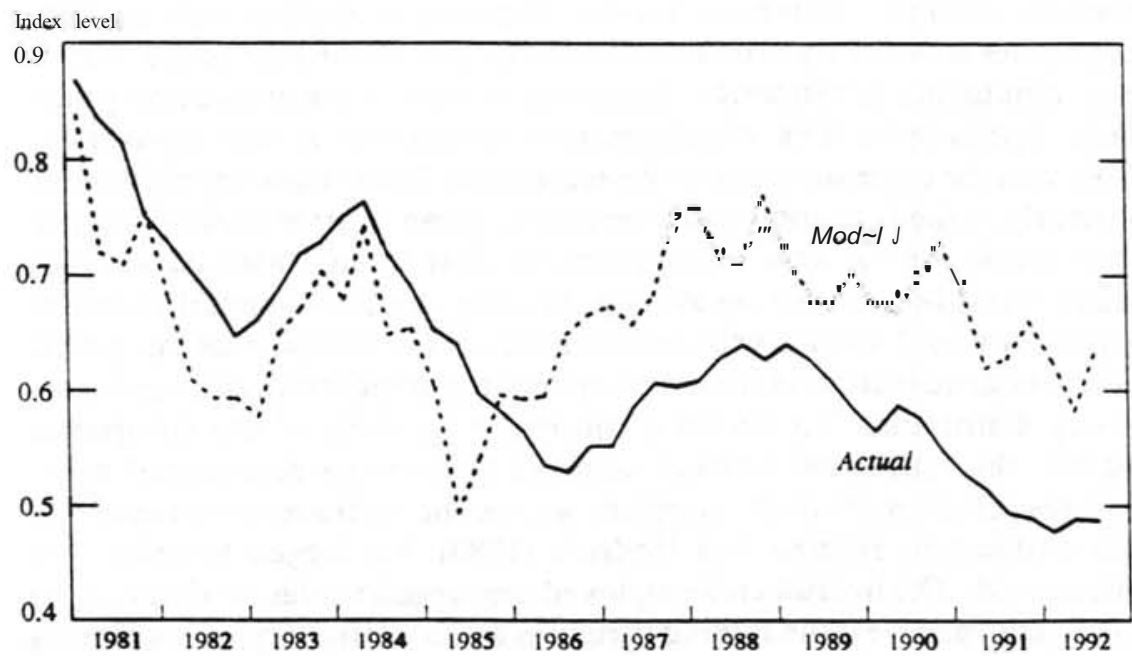

Sources: IMF, International Financial Statistics. and the authors.

\section{Expansion of Supply}

As argued above, the large expansion in commodity exports in the 19805 suggests the presence of strong supply-side forces in commodity markets. To proxy for supply developments, we incorporate the volume of primary commodities imported by the industrial countries as a determinant of the price equation. in a manner analogous to equation (8). As noted earlier. to counter the possible endogeneity bias introduced in the regression by the supply variable. this variable was also instrumented out, using lagged values as instruments. The estimated equation is the following:

$$
q,=\mathrm{r} 30+r_{l} I P / V_{, i}+r 32 R,+r 33 Q_{,}+u, .
$$

Equation (10) was estimated using quarterly data for 1971:1-1992:III. To elude nonstationarity problems (see Reinhart and Wickham (1994) for a fuller discussion of the time-series properties of commodity prices), we avoid employing levels (or log levels) in the econometric analysisY The

11 The augmented Dickey-Fuller (ADF) and Phillips-Perron (PP) tests indicate that all the variables of interest have unit roots (are nonstationary). The results ofthese tests for commodity prices are reported in Reinhart: and Wickham (1994), and the results for the other variables are available upon request. 
seasonality patterns evident in some of the regressors and instruments are dealt with by using four-quarter differences (rather than first differences) of all the variables. This filter has the advantage of simultaneously eliminating the stationarity problems as well as the seasonality issues. However, employing four-quarter changes does raise some estimation problems. Specifically, this transformation introduces a moving-average process in the error structure of the regression. Since the observations are quarterly, a shock to commodity prices in a given quarter could affect the error terms for the next three quarters-that is. the disturbances will follow a third-order moving average process. An instrumental variables approach would yield consistent estimates of the coefficients but not of the covariance matrix. as the errors are no longer identically and independently distributed. To obtain a consistent estimate of the covariance matrix, the estimation strategy adopted follows the generalized leastsquares (GLS) procedure, therefore we use the variance-covariance matrix outlined in Hansen and Hodrick (1980). No lagged variables are introduced. The instruments employed are lagged values of all the righthand side variables (the filtered variables are all stationary, so employing lagged values as instruments does not pose any estimation problems), lagged values of the four-quarter changes in the log of real oil prices, and the real fiscal deficit in the United States.

The estimation results, reported in the first row of Table 5, have a number of satisfactory features. and generally support the theoretical priors. First, the coefficient on the supply variable has the correct sign (indicating that an expansion in supply, other things being equal, reduces commodity prices) and the relationship is statistically significant.. The supply coefficient at -0.9 suggests that an increase in commodity supply translates to an almost proportional decline in its price. which is in line with the general view that the demand for commodities is inelastic (see

Table 5. A Model of Real Commodity : Prices with Alternative Measures of Demand: Instrumental Variables Ivith Consistent Estimation of the Variance-Covariance Matrix 1971:I-I992:UI".

\begin{tabular}{lccccc}
\hline $\begin{array}{l}\text { Constant } \\
\text { term }\end{array}$ & $\underline{I P l v}$. & $\underline{I P W}$ : & $\underline{R}$ & $\underline{Q}$ & $\underline{R^{2}}$ \\
\hline-0.03 & 1.40 & - & -0.62 & -0.96 & 0.76 \\
$(-1.39)$ & $(5.02)$ & - & $(-4.18)$ & $(-4.17)$ & 0.76 \\
-0.04 & - & 1.54 & -0.62 & -0.95 & 0.76 \\
$(-1.66)$ & & $(5.57)$ & $(-4.32)$ & $(-4.24)$ & \\
\hline
\end{tabular}

- Definitions of all the variables appear in Appendix, II. Four-quarter differences of log levels are used for all variables. The above equations include no lagged variables. The numbers in parentheses are t-statistics. 
World Bank (1994») Second, the "excess sensitivity" of commodity prices to real exchange rates that characterized the demand-driven model disappears altogether. In effect, the coefficient of the real exchange rate, at -0.62 , is now within the dictates of theory: Third, the parameter estimates appear to be robust irrespective of the choice of sample period, which will be discussed further. Fourth, and more important (as discussed below), the predictive performance of this specification is superior to specifications that exclude a supply variable and outperform the forecasts from a random walk model at longer-term forecast horizons.

\section{Fall in Demand from Former Soviet Union}

Some of the impact on commodity prices of the developments in the former Soviet Union is already captured in the supply proxy. Recall that supply is proxied by primary commodity imports of the largest industrial countries. Hence, these import figures (particularly for Europe) already include imports of metals from the former Soviet Union. However, as illustrated in Table 1, the effect on commodity markets of the economic developments in the countries of the former Soviet Union and Eastern Europe has also been characterized by the large drop in the domestic demand for commodities since 1989. Even in those commodity markets where transition economies are net exporters, the increases in exports can largely be traced to a fall in domestic demand that broadened the exportable balances, as discussed in Section I. Because this drop in the demand for commodities was closely associated with the drop in aggregate output, we proxy this "aggregate demand factor" by incorporating the countries of Eastern Europe and the former Soviet Union into our index of industrial production.

Therefore, we construct a new aggregate index of industrial production, $I P W^{\prime}$, in which the transition economies are represented with a weight that corresponds to their share in commodity market imports. The equation to be estimated thus becomes

$$
q_{t}=\beta_{0}+\beta_{1} I P W_{t}^{\prime}+\beta_{2} R_{t}+\beta_{3} Q_{t}+u_{t} .
$$

Estimation results, displayed in row 2 of Table 5, are encouraging, although the significance levels show only a minor improvement relative to the specification that does not include developments in the transition economies (for the entire sample). More important, Figure 3 shows that there is a marked improvement in the out-of-sample predictive ability of this equation, most noticeable in 1989-92, when the output collapse in the transition economies materializes. In Figure 3 we plot dynamic fore- 
Figure 3. Real Non-Oil Commodity. Prices: Actual and Forecasts (1980-1.0)

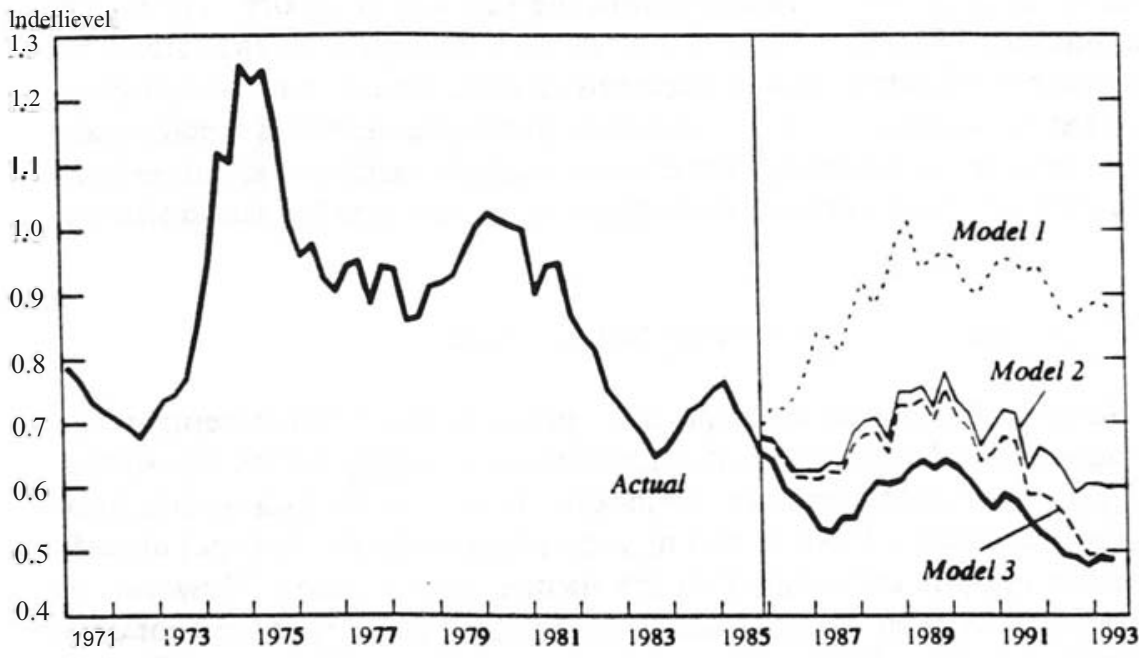

Sources: IMF. International Financial Statistics, and the authors.

casts obtained by applying the three estimated specifications. Model 1, corresponding to equation (9), includes conventional demand-side determinants only; model 2, corresponding to equation (10), adds a supply proxy to the estimated equation; and model 3, corresponding to equation (11), incorporates the transition economies in the measure of world industrial production. The poor forecasting performance of model 1 after

Table 6. Descriptive Statistics of Actual Commodity Prices and Dynamic Forecasrs. 1985:/-1992:111"

\begin{tabular}{lcccc}
\hline & Actual & Modell & Model 2 & Model 3 \\
\hline Mean & 0.57 & 0.88 & 0.67 & 0.64 \\
Standard deviation & 0.05 & 0.08 & 0.05 & 0.07 \\
Minimum value & 0.48 & 0.68 & 0.59 & 0.49 \\
Maximum value & 0.65 & 1.01 & 0.78 & 0.75 \\
$\begin{array}{l}\text { Pairwise correlation } \\
\quad \text { with actual values }\end{array}$ & 1,00 & 0.03 & 0.81 & 0.92 \\
$\begin{array}{l}\text { Standard error of } \\
\quad \text { the correlations }\end{array}$ & - & $(0.14)$ & $(0.11)$ & $(0.07)$ \\
\hline
\end{tabular}

"These forecasts are plotted on Figure 3. 
Table 7. Estimaces of Alcernacive Specificacions Used for Dvnamic Forecasts of Commoditu Prices. 1971:/-1984:IV"

\begin{tabular}{|c|c|c|c|c|c|c|}
\hline $\begin{array}{l}\text { Model } \\
\text { number }\end{array}$ & $\begin{array}{c}\begin{array}{c}\text { Constant } \\
\text { term }\end{array} \\
\end{array}$ & $\not P W$ & $\mathbb{P P} W_{2 L}$ & $R$ & Q & $R^{2}$ \\
\hline 1 & $\begin{array}{c}-0.05 \\
(-1.94)\end{array}$ & $\begin{array}{c}1 . .57 \\
(12.71)\end{array}$ & ${ }^{*}$ & $\begin{array}{c}-0.68 \\
(-2.44)\end{array}$ & $\bullet$ & 0.55 \\
\hline 2 & $\begin{array}{c}-0.03 \\
(-1.01)\end{array}$ & $\begin{array}{c}1.36 \\
(5.66)\end{array}$ &.$^{*}$ & $\begin{array}{c}-0.68 \\
(-3.23)\end{array}$ & $\begin{array}{c}-0.85 \\
(-3.16)\end{array}$ & 0.75 \\
\hline 3 & $\begin{array}{r}-0.04 \\
(-1.53) \\
\end{array}$ &.$^{*}$ & $\begin{array}{r}1.74 \\
(5.98) \\
\end{array}$ & $\begin{array}{r}-0.65 \\
(-3.29) \\
\end{array}$ & $\begin{array}{r}-0.85 \\
(-3.27) \\
\end{array}$ & 0.75 \\
\hline
\end{tabular}

- Four-quarter differences of log levels are used for all variables. The above equations include no lagged variables. The numbers in parentheses are c-statistics. Asterisks indicate the variable was not included in the equation.

1984 and a much more adequate performance of model 3 can easily be established from the figure. ${ }^{12}$ Table 6 provides some summary information of the forecasts produced by the three models. It shows that the pairwise correlation with actual values is contrastingly higher for model 2 and model 3.

A further assessment of the performance of the estimated equations was obtained by comparing their forecasting abilities to an alternative, purely time-series-based, forecasting model.. The logical and customary alternative specification is the random walk model.. This type of test has been applied to exchange rate models. For example, Meese and Rogoff (1983a and 1983b) have shown that (nominal) exchange rate models routinely fail to predict out of sample relative to the random walk model in the floating rates period (see also Mussa (1986)). In the context of commodity prices. Kaminsky and Kumar (1990) showed that a random walk model is also the natural specification for a purely time-series-based forecasting equation.

Such a test underscores the superior predictive performance of model 3. The three different structural equations were re-estimated for the sample period 1971-84 and then dynamically simulated over 1985-92. The results of these estimations are presented in Table 7. As noted earlier. the parameter estimates appear to be robust irrespective of the choice of sample period. For example, the estimation results presented in Table 5, which span the entire 1971:I-1992:III sample, are comparable in both fit and order of magnitude to the parameters ; of the estimation

${ }_{12}$ It is important to note that even for model 3 overprediction continues to be a problem during 1985-92.As will be discussed in the concluding section, such overprediction may arise from not explicitly modeling the role of other factors (such as oil prices Appendix: $\mathrm{I}-$ )r agricultural policies in the industrial countries) and events (such as the breakdown of several commodity agreements during that period) that have an influence over commodity price behavior. 
Table 8. Out-of-Sample Forecasting Performance of Alternative Models: A Comparison to a Random Walk Estimation period: 1971:/-1984:W: Forecast period 1985:/-1992:IJI"

\begin{tabular}{|c|c|c|c|c|c|c|}
\hline \multirow[b]{2}{*}{ Horizon } & \multicolumn{2}{|c|}{$\begin{array}{l}\text { Modell } \\
\text { "Dornbusch demand- } \\
\text { driven model" }\end{array}$} & \multicolumn{2}{|c|}{$\begin{array}{c}\text { Model 2 } \\
\text { "Adding a supply variable" }\end{array}$} & \multicolumn{2}{|c|}{$\begin{array}{c}\text { Model } 3 \\
\text { "Full structural } \\
\end{array}$} \\
\hline & RMS error ${ }^{b}$ & Theil $u$ & RMS error ${ }^{b}$ & Theil $u$ & RMS error ${ }^{\mathrm{b}}$ & Theil " \\
\hline 1 quarter & .324 & 16.385 & .106 & 5.353 & .072 & 3.645 \\
\hline 4 quarters & .340 & 6.059 & .111 & 1.974 & .075 & 1.339 \\
\hline 8quarters & .353 & 4.332 & .115 & 1.416 & .076 & .939 \\
\hline 12 quarters & .363 & 4.044 & .116 & 1.298 & .073 & .819 \\
\hline 16 quarters & .367 & 4.596 & .117 & 1.466 & .068 & .848 \\
\hline 20 quarters & .381 & 5.388 & .119 & 1.674 & .059 & .839 \\
\hline 24 quarters & .393 & $3 . \mathrm{H} 64$ & .117 & 1.153 & .043 & 426 \\
\hline 28 quarters & .392 & 2.395 & .113 & .694 & .020 & .124 \\
\hline 31 quarters & 393 & 1.222 & 110 & 537 & .001 & .004 \\
\hline
\end{tabular}


results summarized in Table 7, which are based on the 1971:1-1984:IV subperiod. Table 8 reports Theil's $u$ statistic, which compares the rootmean-squared error of the model forecast to the random walk model forecast of no change over the whole horizon. A value in excess of one indicates that the model underperformed the random walk forecast over the corresponding horizon. The results indicate that model 1 is outperformed by the random walk model over the whole forecast period of neadly eight years. Model 2 has much smaller prediction errors, but it only overtakes the forecasting ability of the random walk model for horizons longer than six years. Model 3 has much smaller forecasting errors and starts to outperform the random walk model for horizons between one and two years.

\section{What Caused the Price Decline?}

The econometric estimation carried out in the previous section permits us to quantify, the relative importance of the different factors that are commonly associated with the decline in the prices of commodities during the last decade. A variance decomposition of the explained change in commodity prices, reported in Table 9, produces a very definite temporal pattern. Supply shocks account for about 40 percent of the explained variance for 1971-84, but this share rises to over 60 percent during 1985-88. Conversely, industrial production in industrial countries accounts for 25 percent of the explained variance of commodity prices in 1971-84, but the proportion falls to just over 5 percent for 1985-88. This result does not suggest that demand conditions in the industrial countries are not an important and systematic determinant of commodity prices (all our results attest to the statistical significance of this variable) but rather that this relatively stable determinant of commodity prices has not been a key factor in explaining the rising variability in commodity prices. 13 Output in the transition economies of Eastern Europe and the former Soviet Union account for a minor fraction of the variance in the early part of the sample, but this share increases to over 26 percent for the period since 1989. The real exchange rate of the U.S. dollar explains a fairly stable proportion of the variance of commodity prices throughout the sample subperiods. $1 \sim$

$\sim$ For a discussion of the volatility of commodity prices, see Reinhart and Wickham (1994).

$\mathrm{t} \sim$ This variance decomposition is net of the fraction of the variance of commodity prices explained by the pairwise covariances of the different explanatory variables (which cannot be attributed to a specific variable) and of the unexplained part (the variance of the regression residual). 
Table 9. Real Commodiev, Prices: Variance DecomoosirionsPercent of the Explained Variation. 1971:I-I992:IIl'

\begin{tabular}{lcccc}
\hline & $\begin{array}{c}I P \mid \Psi_{;} \\
\text {(Industrial } \\
\text { countries) }\end{array}$ & $\begin{array}{c}I P \mid \eta_{;} \\
\text {(Former Sowiet } \\
\text { Union) }\end{array}$ & $R_{\boldsymbol{t}}$ & Q, \\
\hline 1971:1-1992:III & 16.7 & 6.7 & 30.1 & 46.5 \\
1971:1-1984:IV & 25.1 & 4.2 & 30.4 & 40.3 \\
1985:1-1988:IV & 5.6 & 0.6 & 32.3 & 61.5 \\
1989:1-1992:III & 7.5 & 26.6 & 27.1 & 38.8 \\
\hline
\end{tabular}

"Ignores covariance terms.

\section{Possible Extensions}

The preceding analysis has addressed several of the problems that have plagued the structural approach to commodity price determination in the past. An estimation strategy that recognizes the endogeneity of the regressors was adopted and two important omitted variables were incorporated in the analysis (commodity supply and demand from the former Soviet Union). Although the empirical results obtained using the richer specification are encouraging, a number of areas remain where the foregoing analysis could be extended.

First, as noted in Reinhart and Wickham (1994), the "unobserved process" of technological change appears to have had an important impact in increasing world commodity supply (particularly of agricultural commodities in developing countries). This impact is only imperfectly captured in our measure of supply, which focuses on industrial country imports of primary commodities. It may be worthwhile to attempt to model this secular (and probably largely irreversible) unobseryed process. is

Second, the increasing share in world production of manufactures of China and the newly industrializing countries implies a larger role in international commodity markets for these countries. Incorporating an explicit account of developments in those economies is therefore increasingly desirable.

Third, since it is often argued that the breakdown of several important international commodity agreements has contributed significantly to the weakness in commodity prices in the 1980 s and 1990 s, it is'reasonable to attempt to account for these discrete events when modeling commodity prices.

${ }_{15}$ Possibly along the lines in which the unobserved process of "financial innovation" is modeled in Arrau. De Gregorio, Reinhart. and Wickham (1991). 
Fourth, agricultural, fiscal, and other policies in industrial countries appear to have some effect on commodity price behavior (see Alogoskoufis and Varangis (1992) and Reinhart (1991)); it may be possible to consider commodity price behavior in the context of a fuller, general equilibrium framework.

And last, the approach adopted in this paper, in line with most of the previous literature, has ignored the role of inventories on commodity prices by treating all commodities as nonstorable and stressing the role of flows versus stocks. A careful empirical treatment of this issue appears important. particularly for categories such as metals.

\section{APPENDIX I}

\section{Effect of Oil Prices}

A number of studies have identified the high level of co-movement between the prices of different commodities. 16 Although this paper is concerned only with the behavior of the aggregate index of non-oil commodities, that literature poses the question of what influence oil prices have on determining the prices of the other commodities. This appendix investigates that linkage and finds that, although the price of oil is a significant explanatory variable, its inclusion in the regression does not fundamentally alter the conclusions drawn in the main section of this paper.

The most logical reason for the inclusion of oil prices is its role as another input in the aggregate production function. 17Thus, for example, for the United States. we could express the cost function as:

$C(y, q, p, \omega)=y A q^{\alpha} p^{\beta} \Omega$,

where $p$ is the relative oil price in terms of U.S. output.. Following this approach. the expression for the non-oil commodity price index would be

$$
\begin{aligned}
& \log q=K+\frac{1}{ \pm=!} \log I P W^{\prime}
\end{aligned}
$$

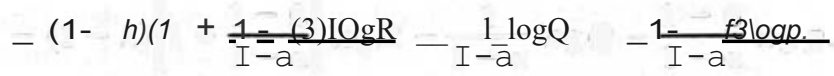

The results of estimating equation (A2) in the same fashion as the previous formulations are displayed in Table A.1.. The coefficient on oil prices is highly significant. and the inclusion of this variable also improves the significance of the other explanatory variables. However, the values of the coefficients are little changed from the specification reponed in Section III, implying that our main conclusions are robust to the inclusion of oil prices in the regression. In effect, the inclusion of oil prices eliminates the sysrematic overprediction of real commodity prices during 1985-92.

16Pindyck and Rotemberg (1990), in fact. estimate that the co-movement among the prices of commodities, taking into account common influences, is excessive and may reflect "herding" behavior in financial markets.

17This approach is followed, for instance, by Holtham (1988), who considers the roles of multiple production inputs. 
Table A.I.. A Multi-input Model of Real Commodity. Prices including Oil: instrumental Variables with Consistent Estimation of the Variance-Covariance Matrix i97I:I-1992:/iL'.'

\begin{tabular}{lccccc}
\hline $\begin{array}{l}\text { Constant } \\
\text { term }\end{array}$ & $\underline{I P W:}$ & $\underline{R}$ & $\underline{Q}$ & $\underline{\underline{ }}$ & $\underline{R^{2}}$ \\
\hline-0.05 & 1.50 & -0.61 & -0.78 & 0.11 & 0.86 \\
$\underline{(-4.30)}$ & $\underline{(7.96)}$ & $\underline{(-6.36)}$ & $\underline{(-6.28)}$ & $\underline{(6.47)}$ & \\
\hline
\end{tabular}

- Four-quarter differences of log levels are used for all variables. The above equation includes no lagged variables. The numbers in parentheses are t-statistics.

\section{APPENDIX II}

\section{Data}

\begin{tabular}{ll}
\hline Variable & Description and sources \\
\hline$I P W$, & Industrial production index for industrial countries. seasonally \\
adjusted. Source: IMF. International Financial Statistics. \\
IPW' \\
Weighted average of industrial production indices for industrial \\
countries. seasonally adjusted. and real GDP for the former \\
Soviet Union. Constructed bv the authors. The annual real \\
GDP series for the former Soviet Union was linearly interpo- \\
lated to construct a quarterly index. Sources: IMF. Interna- \\
tional Financial Statistics and World Economic Outlook. \\
IMF non-oil all-commodity index deflated by the U.S. GNP de- \\
flator. Sources: IMF. International Financial Statistics. and \\
U.S. Depanment. of Commerce. \\
IMF index of the real exchange rate of the United States rela- \\
tive to other industrial couxitries. Based on value added defla- \\
tors in manufacturing. Source: IMF. International Financial \\
Statistics. \\
Primary' commodity imports excluding oil denominated in U.S. \\
dollars for 14 industrial countries. including the United States. \\
deflated by the IMF non-oil all-commodity index. Constructed \\
by the authors from the following sources: IMF. International \\
Financial Statistics and Supplement. on Trade Statistics. and \\
United Nations. Trade Data Svstems. \\
U.S. federal budget deficit (unified budget basis) deflated by the \\
U.S. GNP deflator.. Used only as an instrument. . Sources: \\
U.S. Department of the Treasury and Office of Management \\
and Budget, and U.S. Department of Commerce. \\
Saudi Arabian benchmark price for light crude deflated by the \\
U.S. GNP deflator. Used as an instrument and as a regressor \\
in the regression reponed in Table A.1 in Appendix, I. \\
Sources: IMF. International Financial Statistics, and U.S. De- \\
partment of Commerce.
\end{tabular}

Note: The 14 industrial countries that comprise the supply index are Austria, Belgium, Canada, Denmark. France. Germanv, Italv, Japan, Netherlands, Norway, Sweden, Switzerland, United Kingdom:and the United States. 


\section{REFERENCES}

Aizenman. Joshua. and Eduardo R. Borensztein. "Debt and Conditionalitv Under Endogenous Terms of Trade Adjustment." Staff Papers. Internar tional Monetary Fund. Vol. 35 (December 1988), pp. 686-713.

Alogoskoufis. George, and Panayotis Varangis, "OECD Fiscal Policies and the Relative Prices of Primary Commodities." "Policy Research Working Paper 955 (Washington: World Bank. 1992).

Arrau, Patricio. Jose De Gregorio, Carmen Reinhart. and Peter Wickham. "The Demand for Money in Developing Countries: Assessing the Role of Financial Innovation," IMF Working Paper 91/45 (Washington: International Monetary Fund. 1991), forthcoming in Journal of Development Economics.

Chu. Ke-Younl1: and Thomas K. Morrison. "The 1981-82 Recession and Non-Oil Primary Commodity Prices." Staff Papers. International Monetary Fund. Vol. 31 (March 1984), pp. 93-140.

---, "World Non-Oil Primary Commodity Markets: A Medium-Term Framework of Analysis," Staff Papers. International Monetary Fund. Vol. 33 (March 1986), pp. 139-84.

Deaton, Angus, and Guy Laroque. "On the Behavior of Commodity Prices," Review of Economic Studies. Vol. 59 (January 1992), pp. 1-23.

Dornbusch. Rudiger, "Policy and Performance Links Between LDC Debtors and Industrial Nations." Brookings Papers on Economic Activity: 2 (1985), pp. 303-356.

---, "Inflation, Exchange Rates. and St:lbilization." Essays in International Finance No. 165 (Princeton, New Jersey: Princeton University, 1986).

Englander. A. Steven, "Commodity Prices in the Current Recovery," Federal Reserve Bank of New York Quarterly Review, Vol. 10 (Spring 1985), pp. 11-19.

Gilbert. Christopher L.. "The Impact of Exchange Rates and Developing Country Debt on Commodity Prices." Economic Journal. Vol. 99 (September 1989), pp. 773-84:

Hansen. Lars Peter. and Robert J. Hodrick. "Forward Exchange Rates as Optimal Predictors of Future Spot Rates: An Econometric Analysis." Journal of Political Economy, Vol. 88 (October 1980), pp. 829-53.

Hausman. J.A., "Specification Tests in Econometrics." Econometrica, Vol. 46 (November 1978), pp. 1251-71..

Holtham. G.H • "Modelling Commodity Prices in a World Macroeconomic Model." in International Commodity Market Models, and Policy Analysis, ed. by O. Guvenen (Dordrecht: Boston: Kluwers. 1988), pp. 221-58.

Kaminsky, Graciela. and Manmohan S. Kumar. "Efficiency in Commodity Futures Markets," Staff Papers. International Monetary Fund. Vol. 37 (September 1990), pp. 670-99.

Leamer, Edward E., "Vector Autoregressions for Causal Inference?" CarnegieRochester Conference Series on Public Policy, Vol. 22 (1985), pp. 255-304.

Meese, Richard A., and Kenneth Rogoff (1983a), "Empirical Exchange Rate 
Models of the Seventies: Do They Fit Out of Sample?"' Journal of International Economics. Vol. 14 (February 1983). pp. 3-2-t

--- (1983b). "The Out-of-Sample Failure of Empirical Exchange Rate Models: Sampiing Error or Misspecification"?" in Exchange Rates and International Macroeconomics. ed. bv Jacob A. Frenkel (Chicago: Universitv of Chicago Press. 1983), pp. 67-i05.

Morriison. Thomas. and Michael Wattleworth, "The 1984-86 Commodity Recession: An Analysis of the Underlying Causes." IMF Working Paper 87nl (Washington: International Monetary Fund. 1987).

Mussa. Michael.. "Nominal Exchange Rate Regimes and the Behavior of Real Exchange Rates: Evidence and Impiications." Carnegie-Rochester Conference Series on Public Policy. Vol. 25 (Autumn 1986), pp. 117-214.

Pindyck. Robert S.. and Julio J. Rotemberg. "The Excess Co-Movement. of Commodity Prices." Economic Journal .-C (1990). pp. 1173-89.

Reinhart. Carmen M.. "Fiscal Policv. the Real Exchange Rate. and Commodity Prices." Staff Papers. Internat'ional Monetary ' Fti'nd. Vol, 38 (Septembe'r 1991). pp. 506-524.

---. and Peter Wickham. "Commodity Prices: Cyclical Weakness or Secular Decline?" Staff Papers. International Monetary 'Fund. Vol, 41 (June 1994), pp. $175-213$

World Bank. Global Economic Prospects and the Developing Countries (Washington: World Bank. 1994). 